\title{
Mechanisms of resistance to immune checkpoint inhibitors
}

\author{
Russell W Jenkins ${ }^{1,2}$, David A Barbie ${ }^{2}$ and Keith T Flaherty ${ }^{\star}, 1$ \\ ${ }^{1}$ Division of Medical Oncology, Massachusetts General Hospital Cancer Center, Harvard Medical School, 55 Fruit Street, Boston, \\ MA 02114, USA and ${ }^{2}$ Department of Medical Oncology, Dana-Farber Cancer Institute, Boston, MA 02215 USA
}

Immune checkpoint inhibitors (ICI) targeting CTLA-4 and the PD-1/PD-L1 axis have shown unprecedented clinical activity in several types of cancer and are rapidly transforming the practice of medical oncology. Whereas cytotoxic chemotherapy and small molecule inhibitors ('targeted therapies') largely act on cancer cells directly, immune checkpoint inhibitors reinvigorate anti-tumour immune responses by disrupting co-inhibitory T-cell signalling. While resistance routinely develops in patients treated with conventional cancer therapies and targeted therapies, durable responses suggestive of long-lasting immunologic memory are commonly seen in large subsets of patients treated with $\mathrm{ICl}$. However, initial response appears to be a binary event, with most non-responders to single-agent $\mathrm{ICl}$ therapy progressing at a rate consistent with the natural history of disease. In addition, late relapses are now emerging with longer follow-up of clinical trial populations, suggesting the emergence of acquired resistance. As robust biomarkers to predict clinical response and/or resistance remain elusive, the mechanisms underlying innate (primary) and acquired (secondary) resistance are largely inferred from pre-clinical studies and correlative clinical data. Improved understanding of molecular and immunologic mechanisms of $\mathrm{ICl}$ response (and resistance) may not only identify novel predictive and/or prognostic biomarkers, but also ultimately guide optimal combination/sequencing of $\mathrm{ICl}$ therapy in the clinic. Here we review the emerging clinical and pre-clinical data identifying novel mechanisms of innate and acquired resistance to immune checkpoint inhibition.

\section{CLINICAL RESPONSE AND RESISTANCE TO IMMUNE} CHECKPOINT INHIBITORS

Monoclonal antibodies targeting co-inhibitory immune checkpoints (e.g., PD-1 and CTLA-4) have demonstrated clinical activity in several malignances, including melanoma, non-small cell lung cancer, renal cell carcinoma, bladder cancer, head and neck squamous cell carcinoma, MSI-high colorectal carcinoma, Merkel cell carcinoma, and Hodgkin lymphoma, and have changed the practice of medical oncology (Pardoll, 2012; Topalian et al, 2015; Sharma et al, 2017). Immune checkpoint inhibitor therapy has been particularly successful in melanoma, for which approved treatments now include anti-PD-1 (nivolumab and pembrolizumab), anti-CTLA-4 (ipilimumab), and combination anti-PD-1/ CTLA-4 regimens (nivolumab-ipilimumab). Long-term survival data for patients with melanoma treated with ipilimumab (antiCTLA-4) indicates $20 \%$ of patients show evidence of continued durable disease control or response 5-10 years after starting therapy (Schadendorf et al, 2015). The response rate for melanoma patients treated with pembrolizumab (anti-PD-1) was $33 \%$ at 3 years with $70-80 \%$ of patients initially responding maintaining clinical response (Ribas et al, 2016a). Combination immunotherapy or dual immune checkpoint blockade (anti-PD-1+antiCTLA-4) has recently shown dramatic response rates in patients with metastatic melanoma (RR 58\%); however, half of patients experienced significant toxicity from the treatment regimen (Larkin et al, 2015; Postow et al, 2015) and survival benefit for this approach has to be demonstrated.

Analysis of clinical trial data can identify three broad populations of patients - (1) those that respond initially and continue to respond (responders), (2) those that fail to ever respond (innate resistance), and (3) those that initially respond but eventually develop disease progression (acquired resistance) (Pitt et al, 2016; Restifo et al, 2016; O'Donnell et al, 2017; Sharma et al, 2017). Challenges remain in defining responders and nonresponders especially given the heterogeneity in patterns of response that can be seen with ICI. Such heterogeneity can be spatial (i.e., different response in different lesions) and/or temporal 
(e.g., stable disease followed by progression), manifesting within a given patient as mixed responses, oligometastatic progression, and/ or stable disease with isolated progression. Despite these complexities, the 'tail' on the survival curve suggests long-term disease control is possible in a significant proportion of patients successfully treated with ICI. This possibility of expanding this long-term clinical benefit to more patients with advanced cancer is thus fueling more focused investigation into the elusive mechanisms of response and resistance to ICI therapy.

\section{MECHANISMS OF ACTION OF IMMUNE CHECKPOINT} INHIBITORS

Mechanisms of innate and acquired resistance to ICI therapy are not fully understood, owing in part to the incomplete understanding of the full complement of clinical, molecular, and immunologic factors associated with clinical response and longterm benefit to ICI therapy. In addition, few immune competent pre-clinical models exist in which tumour regression is induced by ICIs (Zitvogel et al, 2016), limiting the ability to recapitulate the diversity of tumour-immune interactions in patients. To frame the discussion of innate (primary) and acquired (secondary) resistance, we must first revisit the model of 'response' to ICI to focus on crucial steps that can be inhibited, bypassed, or blocked by the tumour, or co-opted by stromal and immune elements of the tumour microenvironment (TME), to subvert the efforts of the immune system to restrain tumour growth.

Although our understanding of the role of PD-1 and PD-L1 on tumour and immune cells continues to evolve (Juneja et al, 2017; Lau et al, 2017), it is generally accepted that successful anti-tumour immune responses following PD-1/PD-L1 blockade require reactivation and clonal-proliferation of antigen-experienced $\mathrm{T}$ cells present in the TME (O'Donnell et al, 2017; Sharma et al, 2017). Generation of tumour-reactive CD8 T cells requires successful processing and presentation of tumour-associated peptide antigens by antigen-presenting cells (APCs, e.g., dendritic cells) and recognition of these antigenic peptides displayed by MHC I/II. A unique $\mathrm{T}$-cell receptor recognises $\mathrm{MHC}$-bound tumour antigen providing the first signal for $\mathrm{T}$-cell activation and full $\mathrm{T}$-cell activation follows the engagement of the co-stimulatory CD28 receptor on T cells by B7 on the APC (Schumacher and Schreiber, 2015). Tumour-specific CD8 T cells subsequently differentiate into effector T-cells, undergo clonal expansion, traffic to the TME, and ultimately kill tumour cells displaying tumour-associated antigen on HLA, via release of cytolytic effector molecules (e.g., granzyme $\mathrm{A} / \mathrm{B}$ and perforin) (O'Donnell et al, 2017). For long-term immunologic memory (and presumably durable disease control), a subset of effector $\mathrm{T}$ cells must differentiate into effector memory $\mathrm{T}$ cells $\left(\mathrm{T}_{\mathrm{EM}}\right.$ ) (Ribas et al, 2016b), under the guidance of CD4+ helper T cells and dendritic cells; these are maintained for life and respond to re-challenge with antigen (Harty and Badovinac, 2008; Farber et al, 2014).

Failure of ICI therapy can result from defects in any of the steps mentioned above, which can be thought of in three simple categories: (1) insufficient generation of anti-tumour T cells, (2) inadequate function of tumour-specific $\mathrm{T}$ cells (Marincola et al, 2000; Bronte et al, 2005), or (3) impaired formation of T-cell memory (O'Donnell et al, 2017; Sharma et al, 2017) (Figure 1). Lack of sufficient or suitable neoantigens, impaired neoantigen processing, and/or impaired presentation of neoantigens can all lead to impaired formation of tumour-reactive T cells (O'Donnell et al, 2017). Inadequate $\mathrm{T}$-cell function can arise through diverse tumour-intrinsic and tumour-extrinsic immune suppressive components of the TME (Pitt et al, 2016), and recent studies have begun to elucidate mechanisms of durable ICI response (Pauken et al, 2016; Sen et al, 2016). We will explore each of these steps in the context of innate and acquired resistance, as well as strategies to overcome these mechanisms of resistance.

INNATE (PRIMARY) AND ACQUIRED (SECONDARY) RESISTANCE

Insufficient anti-tumour T-cell generation. Tumours can evolve to evade both innate and adaptive arms of the immune system (Gajewski et al, 2013), thereby rendering ICI therapy ineffective (Pitt et al, 2016; Restifo et al, 2016). Tumour-intrinsic mechanisms of immune evasion include genetic and epigenetic alterations to influence neoantigen formation, presentation, and/or processing, as well as alterations in cellular signalling pathways that disrupt the action of cytotoxic $\mathrm{T}$ cells (Pitt et al, 2016). Tumour-extrinsic mechanisms involve non-cancerous stromal or immune cells, or other systemic influences (e.g., host microbiota) (Joyce and Fearon, 2015; Pitt et al, 2016) that can act in concert with cancer cells to promote growth and resistance to ICI.

Successful ICI treatment reactivates $\mathrm{T}$ cells directed at tumourspecific mutant proteins (Gubin et al, 2014), and lack of suitable neoantigens and alterations in antigen processing and/or presentation is associated with impaired anti-tumour immune response (Schumacher and Schreiber, 2015). Mutational burden is a tumour-intrinsic feature correlated with anti-tumour immune response and response to ICI, presumably by virtue of enhanced neoantigen formation from increased number of non-synonymous single nucleotide variants (Schumacher and Schreiber, 2015; Van Allen et al, 2015). Tumour types harbouring high levels of nonsynonymous mutations (e.g., melanoma, lung, and bladder) (Lawrence et al, 2013) are among those with highest response rates to ICI. Consistent with this notion, DNA-mismatch repair deficiency leading to microsatellite instability is associated with enhanced response to PD-1 blockade (Le et al, 2015, 2017).

Importantly, alterations in genes encoding components of the antigen processing and/or presentation apparatus (e.g., class I MHC, $\beta 2$-microglobulin (B2M)) can also lead to ICI resistance. Downregulation of HLA class I molecules and loss of (B2M) expression have been described. Loss of B2M expression results in impaired cell surface expression of MHC class I, which in turn impairs antigen presentation to cytotoxic $\mathrm{T}$ cells (Zaretsky et al, 2016). Neoantigen evolution may underlie aspects of acquired resistance (a) via outgrowth of tumour cell clones that never expressed the neo-Ag, despite effective killing of all other clones, or (b) acquisition of genetic changes that result in loss of neo- $\mathrm{Ag}$ expression. Although clonal neoantigens are associated with response to ICI therapy (McGranahan et al, 2016), evolution of the mutational landscape has been described in patients who developed acquired resistance to ICI (Anagnostou et al, 2016).

Strategies to promote immunogenic cell death (e.g., chemotherapy and radiation) or to enhance antigen presentation by stimulating innate immune responses and dendritic cell function (e.g., type I IFN, TLR ligands, LIGHT, and oncolytic viruses) may promote formation or presentation of suitable neoantigens in tumours with a non-inflamed, immune cell poor TME (Pitt et al, 2016; O’Donnell et al, 2017). In addition, promoting dendritic cell migration, maturation, and function via blockade of immunosuppressive factors (e.g., VEGF, IL-10, and TGF- $\beta$ ), may permit adequate T-cell priming and cooperate with ICI (Pitt et al, 2016; O'Donnell et al, 2017). HLA-independent tumour killing via natural killer cells (e.g., anti-KIR) (Guillerey et al, 2016) may be an option in tumours in which HLA neoantigen presentation is insufficient to promote cytotoxic T-cell killing.

Specific oncogenic signalling pathways can also influence the extent and type of intratumoural immune infiltration. Loss of PTEN is associated with increased levels of CCL2 and VEGF, diminished infiltration of $\mathrm{T}$ cells, and resistance to $\mathrm{PD}-1$ blockade 
(Peng et al, 2016), and biallelic PTEN loss was recently reported in an isolated non-responding lesion in a patient with near complete response to PD-1 blockade (George et al, 2017). Alterations in $\beta$ catenin/WNT signalling caused decreased CCL4 production, which led to diminished infiltration of $\mathrm{CD} 103+$ dendritic cells and impaired anti-tumour immune responses (Spranger et al, 2015). The context of these mutations also influences that type of immune infiltration. For example, loss of STK11/LKB1 in the setting of an oncogenic KRas mutation promotes elaboration of IL-6, which recruits neutrophils, decreases T-cell infiltration, and was associated with higher levels of T-cell exhaustion markers (PD-1, CTLA-4, and TIM3), and lower expression of PD-L1 on tumour cells (Koyama et al, 2016a). The recently described innate PD-1 resistance (IPRES) gene signature identified a set of immune suppressive cytokines, EMT transcription factors, and proangiogenic factors associated with innate resistance to PD-1 blockade (Hugo et al, 2016). Of note, gene signatures enriched in non-responding patients also include signatures for woundhealing, EMT, and treatment/resistance to MAPK pathway inhibition (Hugo et al, 2015, 2016). Intriguingly, the receptor tyrosine kinase AXL, whose upregulation is associated with a reversible cell state marked by NF- $\kappa \mathrm{B}$ activation and resistance to BRAFi/MEKi (Konieczkowski et al, 2014) is a component of the IPRES (Hugo et al, 2016). It is tempting to speculate that the IPRES may be part of a multigenic, reversible transcriptional program that could be modulated to influence sensitivity to ICI therapy.

Cell state changes are tumour intrinsic, epigenetic events that often result from reversible chromatin modification through removal or addition of methyl or acetyl marks to DNA or histones. Epigenetic modifying agents (EMAs), including DNA- methyltransferase inhibitors and histone modifiers, can act on tumour cells influencing expression of components of antigenprocessing and presentation machinery (e.g., TAP, HLA class molecules, and B2M), novel tumour-associated antigens (e.g., cancer-testis antigens), and cytokines (Heninger et al, 2015). Restoration of Th1 cytokine production and enhanced responsiveness to checkpoint blockade has been demonstrated following treatment with DNMT or EZH2 inhibitors (Peng et al, 2015). Altered methylation of non-coding regions of the genome may also impact response to immunotherapy. Hypomethylating agents (e.g., 5 -aza cytidine) can induce innate immune responses (Roulois et al, 2015), influence T-cell priming and effector function, modulate immune suppressive cells within the TME (Kim et al, 2014), and enhance response to ICI through induction of endogenous retroviral elements (ERVs) (Chiappinelli et al, 2015). Interestingly, tumour-specific ERVs have been associated with anti-tumour cytolytic activity and immune gene cell enrichment (Rooney et al, 2015). Although the strength and directionality of this relationship between ERVs and immune infiltration and activation, as well as the role for EMAs as adjuvants for ICI therapy via ERV modulation, requires further investigation, there is growing interest in the role of ERV induction as a mechanism to enhance response to PD-1 blockade (Goel et al, 2017).

Inadequate anti-tumour T-cell effector function. Following successful neoantigen presentation/cross-presentation and T-cell priming, the expanded repertoire of anti-tumour $\mathrm{T}$ cells faces an inhospitable TME that may preclude proper T-cell function, thereby limiting the efficacy of ICI therapy (Pitt et al, 2016; Sharma et al, 2017). These tumour-intrinsic and tumour-extrinsic factors

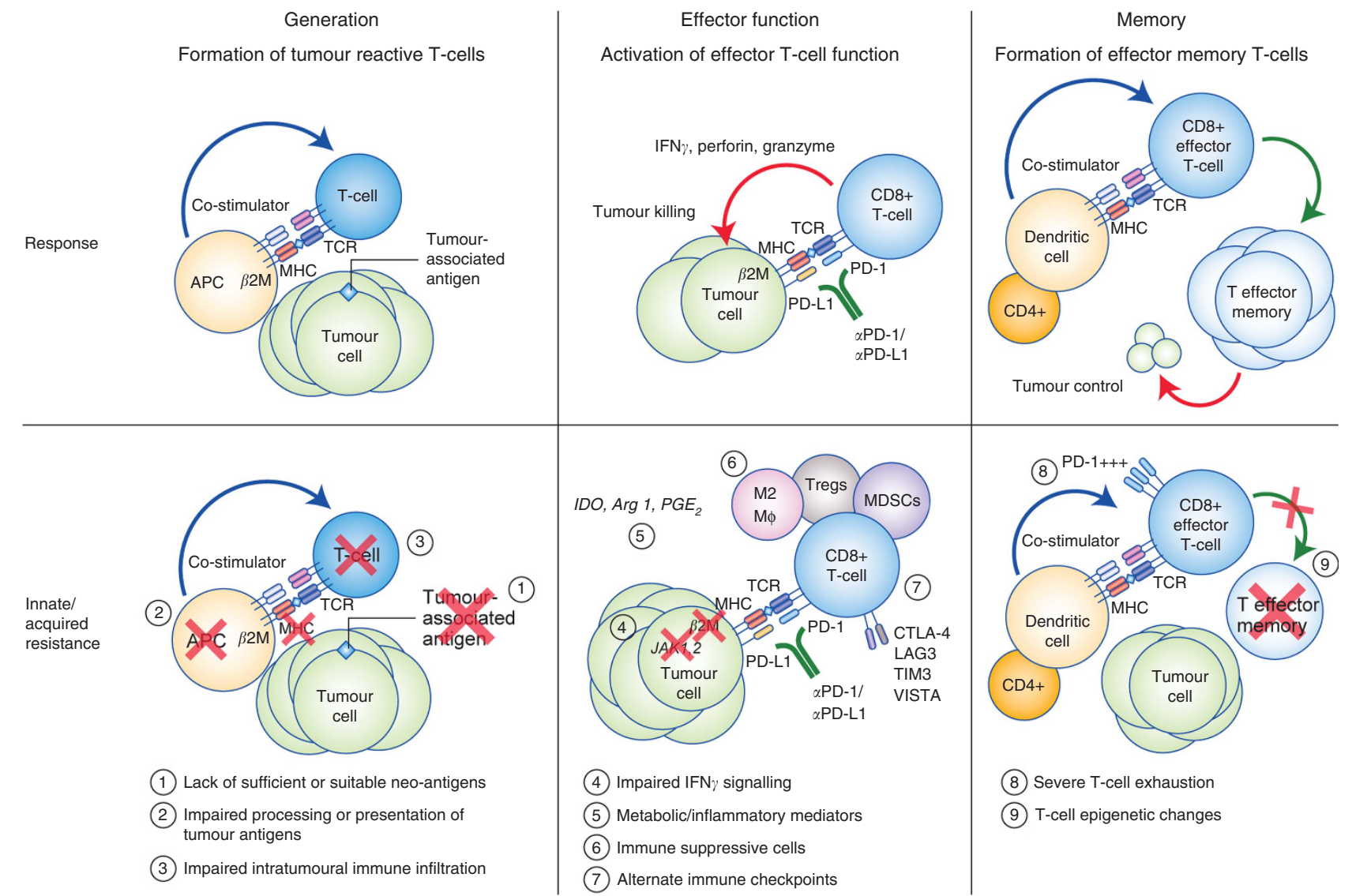

Figure 1. Response and resistance to ICl therapy. Upper panel: schematic detailing basic steps involved in generation of tumour-specific T cells, effector T-cell function, and formation of memory T cells. Lower panel: schematic detailing putative mechanisms of innate and/or acquired resistance to $\mathrm{ICl}$ therapy. 
include mutations in key effector pathways, high levels of PD-L1 on tumour cells (and immune cells), high levels of alternate immune checkpoints or co-inhibitory receptors on $\mathrm{T}$ cells (e.g., PD-1, CTLA-4), high levels of immune suppressive cytokines or metabolites, and associated recruitment of immune suppressive cells (e.g., myeloid-derived suppressor cells (MDSCs) and regulatory T cells (Tregs)) (O’Donnell et al, 2017).

Mutations in immune effector signalling pathways are capable of nullifying the impact of tumour-specific T cells. Whole exome sequencing of tumours from patients that developed resistance following initial clinical response to $\mathrm{PD}-1$ blockade revealed mutations in Janus kinases 1 and 2 (JAK1/JAK2) (Zaretsky et al, 2016). These mutations were detected in association with deletion of the wild-type allele resulting in total loss-of-function and loss of interferon responsiveness. This study also described a truncating mutation in B2M, the loss of which resulted in impaired cell surface expression of MHC class I, and defective antigen presentation. The frequency of such mutations appears low based on limited studies to date, but more widespread sequencing may identify additional mutations that lead to innate and/or acquired resistance to ICI therapy (Zaretsky et al, 2016; Shin et al, 2017). Consistent with these reports of loss-of-function mutations in JAK1/2 as an innate and acquired resistance mechanism, in vivo CRISPR screening using a mouse model of melanoma demonstrated that deletion of IFN $\gamma$ receptors (Ifrngr1 and Ifngr2) and JAK/STAT pathway components (Jak1, Jak2, and Stat1) resulted in resistance to PD-1 blockade (Manguso et al, 2017). An intriguing pre-clinical observation in an immune-competent melanoma model is that acquired resistance to ICI blockade could be overcome by inhibiting JAK1/JAK2 signalling, suggesting that JAK/STAT signalling may have a more complex role in mediating response and resistance to ICI (Benci et al, 2016). Importantly, the impact of systemic JAK1/2 inhibition with a small molecule inhibitor (e.g., ruxolitinib) almost certainly differs from tumourspecific loss of functional JAK1 and/or JAK2 signalling. Moreover, ICI-resistant cells were derived using anti-CTLA-4 antibody treatment, which promotes Treg depletion (Simpson et al, 2013), a property yet to be demonstrated for human anti-CTLA-4 antibodies (e.g., ipilimumab). In light of reports of acquired resistance to cancer immunotherapy through immunoediting (Takeda et al, 2017) or acquired resistance via induction of a multigenic resistance programme (Benci et al, 2016), further studies will be required to evaluate the impact of interferon signalling as a driver of resistance to ICI therapy.

Within the TME, PD-L1 is constitutively expressed in response to oncogenic signalling, or induced in response to inflammatory cytokines. The physiologic role of immune checkpoints is to maintain self-tolerance and minimise the extent and duration of inflammatory responses, but is co-opted by tumours to promote immune escape via adaptive immune resistance (Keir et al, 2008; Pardoll, 2012). Amplification of a region on chromosome 9p24.1 (containing PD-L1, PD-L2, and JAK2) in Hodgkin lymphoma leads to constitutive overexpression of PD-L1 and is thought to explain high clinical response rate to PD-1 blockade (Ansell et al, 2015). PD-L1 expression is induced in response to both cellintrinsic signalling and in response to immune cell-derived soluble factors, such in response to IFN- $\gamma$ released by effector T cells, and may actually develop in response to T-cell infiltration rather than because of it (Spranger et al, 2013). Although intratumoural PD-L1 expression can enrich for responders (e.g., NSCLC) (Reck et al, 2016), PD-L1 remains an imperfect biomarker and PD-L1 status neither guarantees nor precludes response to PD-1/PD-L1 blockade (Kluger et al, 2017). Although the impact of PD-L1 expression on tumour cells $v s$ immune or stromal cells in patients remains unclear, murine studies have confirmed the contribution of PD-L1 on both tumour and immune cells as critical to determine response to PD-1 blockade (Juneja et al, 2017; Lau et al,
2017). In addition, preliminary evidence in serial tumour biopsies of PD-1 antibody-treated melanoma patients suggests that induction of PD-L1 expression on tumour cells early in the course of therapy improves response prediction (Chen et al, 2016).

Functional exhaustion of CD8 $+\mathrm{T}$ cells has been well described in chronic viral infections and in cancer, but great heterogeneity exists evidenced by distinct different populations of PD- $1^{+} \mathrm{CD} 8^{+}$ $\mathrm{T}$ cells that respond differently to anti-PD-1 treatment (Blackburn et al, 2008; Paley et al, 2012). For example, partially exhausted PD$1^{+}$CTLA $-4^{+}$CD8 ${ }^{+}$infiltrating T cells have been correlated with PD-1 response (Daud et al, 2016). Exhausted PD- $1^{+}$CD8 ${ }^{+} \mathrm{T}$ cells display a distinct chromatin landscape compared with effector $\mathrm{T}$ cells and $\mathrm{T}_{\mathrm{EM}}$ cells (Pauken et al, 2016; Sen et al, 2016), and these epigenetically distinct $\mathrm{T}$-cell states influence whether or not exhausted PD $-1^{+}$T cells can be reprogrammed to avoid terminal exhaustion and dysfunction (Philip et al, 2017). Evaluation of the specific subsets of $\mathrm{CD}^{+} \mathrm{T}$ cells that are expanded in response to PD-1/PD-L1 blockade identified a unique subset of CD8 ${ }^{+} \mathrm{PD}-1^{+}$ $\mathrm{T}$ cells that share features of T-follicular helper cells, CD8 memory precursors, and stem cells (Im et al, 2016), and resemble CXCR5 ${ }^{+}$ $\mathrm{CD}^{+}$follicular $\mathrm{T}$ cells (He et al, 2016; Leong et al, 2016; Utzschneider et al, 2016). Recent profiling of tumour-infiltrating $T$ cells using mass cytometry revealed distinct mechanisms of action of PD- 1 and CTLA-4 blockade, demonstrating that PD-1 blockade reinvigorates $\mathrm{CD}^{+}$T-cell responses, and CTLA-4 blockade results in the expansion of Th1-like $\mathrm{CD}^{+}$cells expressing the co-stimulatory ligand ICOS (Wei et al, 2017). Expression of alternative co-inhibitory immune checkpoints (e.g., CTLA-4, TIM3, LAG-3, and VISTA) has been associated with resistance to PD-1 blockade (Thommen et al, 2015; Koyama et al, 2016b), and combination checkpoint blockade using LAG-3 ${ }^{+}$PD-1 (Woo et al, 2012) and TIM- $3^{+}$PD-1 (Sakuishi et al, 2010) has demonstrated improved responses in preclinical models. Although these studies suggest crucial roles for distinct sub-populations of PD- ${ }^{+} \mathrm{CD} 8{ }^{+}$ $\mathrm{T}$ cells, further investigation will be required to determine how to target specific CD8 and CD4 T-cell subsets to overcome primary and acquired resistance.

PD-L1-independent mechanisms of immune escape include alternate immune checkpoints or co-inhibitory receptors, immune suppressive cytokines, immune inhibitory metabolites, and immune suppressive cells (Pitt et al, 2016; O’Donnell et al, 2017; Sharma et al, 2017). Immune suppressive cell types that have been shown to influence ICI efficacy in pre-clinical models include Tregs, MDSCs, Th2 $\mathrm{CD}^{+}{ }^{+} \mathrm{T}$ cells, and M2-polarised tumour-associated macrophages (Pitt et al, 2016; O'Donnell et al, 2017; Sharma et al, 2017). These cell types individually and collectively promote an immune suppressive TME that prevent anti-tumour cytotoxic and Th1-directed T-cell activities, primarily through the release of cytokines, chemokines, and other soluble mediators (Pitt et al, 2016; Sharma et al, 2017). Depletion of these immune suppressive cell types (e.g., MDSCs and Tregs) has experimentally been shown to enhance anti-tumour immune responses overcoming innate resistance (Highfill et al, 2014; Ngiow et al, 2015). Myeloid- and cancer-cell derived indolamine-2,3-dioxygenase (IDO) catabolises tryptophan to the immune suppressive kynurenine (Platten et al, 2014). Interestingly, another immune suppressive enzyme, arginase 1, was recently shown to cooperate with the IDO pathway to inhibit dendritic cell function (Mondanelli et al, 2017). Recently, tumour-associated macrophages were demonstrated to directly limit PD-1 blockade by removing anti-PD- 1 antibodies from PD- $1^{+} \mathrm{CD} 8^{+} \mathrm{T}$ cells in a Fc $\gamma \mathrm{R}$-dependent manner (Arlauckas et al, 2017). There is also emerging data that additional metabolic (e.g., glucose consumption, lactate production, and cholesterol metabolism) and inflammatory pathways (e.g., cyclooxygenase-2/prostaglandin E2) can simultaneously impact both tumour cells and immune cells (Pitt et al, 2016). 
Impaired formation of T-cell memory. The most compelling clinical evidence for the success of ICI relates to the potential for long-term, durable clinical benefit. Thus, although ICI may temporarily re-invigorate CTLs to enhance tumour control, if formation of $\mathrm{T}_{\mathrm{EM}}$ cells is impaired then clinical response could fade leading to acquired resistance or recurrence of disease following discontinuation of therapy. Expansion of intratumoural $\mathrm{T}_{(\mathrm{EM})}$ in response to PD-1 blockade has been demonstrated, and is more pronounced in patients responding to therapy (Ribas et al, 2016b), suggesting a key role for $\mathrm{T}_{\mathrm{EM}}$ cells in anti-PD-1 action and clinical response (O'Donnell et al, 2017). The cellular and molecular mechanisms of $\mathrm{T}_{\mathrm{EM}}$ expansion following PD-1 blockade are not fully understood, however, recent studies have identified distinct transcriptional programmes associated with naive, acute effector, memory, and exhausted T-cell states (Pauken et al, 2016; Sen et al, 2016). There is emerging evidence that $\mathrm{T}$-cell exhaustion is associated with epigenetic changes that promote a transcriptional landscape distinct from effector or memory CD8 T cells (Sen et al, 2016). Importantly, these epigenetic changes appear to limit the durability of CD8 T-cell function following PD-1 blockade (Pauken et al, 2016). Reacquisition of memory $\mathrm{T}$-cell response may be limited during conditions if tumour antigen persists, as occurs in patients with higher tumour burden (Huang et al, 2017), indicating that future efforts to augment existing new T-cell responses or prime new populations of $\mathrm{T}$ cells may be required to generate durable anti-tumour T-cell memory.

\section{SUMMARY AND FUTURE DIRECTIONS}

Several clinical trials of combinations of immunotherapeutic agents with targeted agents, cytotoxic chemotherapy, and/or radiation are underway, all in the effort to provide long-lasting disease control to more patients (Buque et al, 2015) (Figure 2). Combination therapies to overcome innate resistance by targeting putative mechanisms of immune evasion within the TME are in various stages of development (Spranger and Gajewski, 2013; Smyth et al, 2016). Cancer vaccines (Ott et al, 2017; Sahin et al, 2017) are showing promise as a means of personalising cancer immunotherapy and potentially enhancing immune memory. Additional research efforts are underway to identify biomarkers associated with resistance and response to ICI, in parallel with early phase clinical testing of novel immune modulatory agents and novel combinations of immune modulators and ICI with other cancer therapies (Mahoney et al, 2015).
Generation

Formation of tumour reactive T-cells

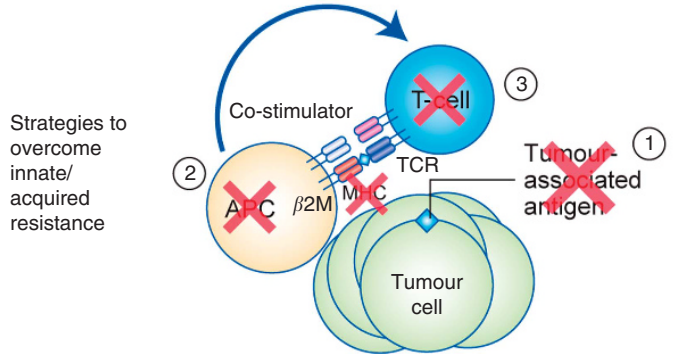

Examples

$\mathrm{ICl}$ combination

Single/dual ICI therapy

$\mathrm{ICl}+$ immune stimulating agents
Effector function

Activation of effector T-cell function

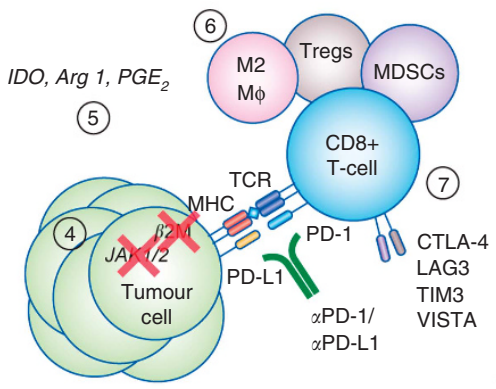

Memory

Formation of effector memory T-cells

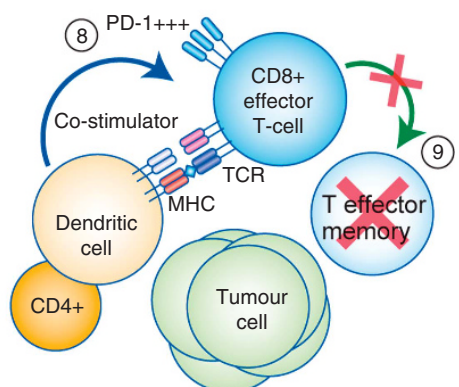

Potential mechanism(s)

Anti-PD-1, anti-PD-L1, anti-CTLA-4, anti-TIM3, anti-LAG3

Anti-OX40, anti-CD137/4-1BB, anti-CD40, anti-ICOS, oncolytic Viruses, TLR agonists, vaccines, NK cell activation (anti-KIR)
(7) Alternate immune checkpoints

(8) Severe T-cell exhaustion

(1) Lack of sufficient or suitable neo-antigens

(2) Impaired processing or presentation of tumour antigens

(3) Impaired intratumoural immune infiltration

(4) Impaired IFN $\gamma$ signalling

(7) Alternate immune checkpoints

$\begin{array}{ll}\mathrm{ICI}+\text { metabolic inhibitors } & \text { IDO inhibitors, adenosine receptor (A2AR) inhibitors } \\ \mathrm{ICl}+\text { targeted therapies } & \begin{array}{l}\text { BRAF + MEK inhibitors, VEGF inhibitors, EGFR inhibitors, } \\ \text { PARP inhibitors, mTOR inhibitors }\end{array} \\ \mathrm{ICI}+\text { epigenetic modifiers } & \begin{array}{l}\text { Histone deacetylase inhibitors, hypomethylating agents } \\ \text { (e.g., DNA methytransferase inhibitors) }\end{array} \\ \mathrm{ICl}+\text { chemotherapy } & \begin{array}{l}\text { Paclitaxel, dacarbazine, carboplatin/paclitaxel, carboplatin/ } \\ \text { gemcitabine }\end{array} \\ \mathrm{ICl}+\text { radiation } & \text { Hypofractionated radiation, stereotactic body radiation }\end{array}$

(5) Metabolic/inflammatory mediators

(6) Immune suppressive cells

(3) Impaired intratumoural immune infiltration

(4) Impaired IFN $\gamma$ signalling

(7) Alternate immune checkpoints

(3) Impaired intratumoural immune infiltration

(4) Impaired IFN $\gamma$ signalling

(9) T-cell epigenetic changes

(1) Lack of sufficient or suitable neo-antigens

(1) Lack of sufficient or suitable neo-antigens

Figure 2. Combination therapies to overcome resistance to $\mathrm{ICl}$ therapy. Putative mechanisms of innate and/or acquired resistance to $\mathrm{ICl}$ therapy. Table listing select approaches for $\mathrm{ICl}$ combination therapeutic approaches (Sharma et al, 2017). 
To date, precision medicine has largely been synonymous with use of molecular and largely genomic features of the tumour to administer specific targeted small molecules and biologics; however, novel and functional precision medicine platforms may offer additional opportunities to tailor therapies for individual patients or patient populations (Friedman et al, 2015). As the mechanisms of response and resistance to immune checkpoint inhibitors are further elucidated, molecular and functional technologies can and should be integrated to develop novel precision immuno-oncology platforms. In addition, development of functional assays to evaluate response and resistance to ICI therapy and novel combinations may require bio-engineering expertise to appropriately model the native tumour immune microenvironment (Hirt et al, 2014). In the short-term, composite biomarkers (e.g., CD8 T-cell abundance + tumoural/stromal PDL1 staining) will likely supplant individual biomarkers (e.g., PD-L1 staining), whereas next-generation molecular and/or functional diagnostics are in development. Ultimately, such precision approaches would be anticipated to identify specific therapies, or therapeutic combinations, to optimise clinical activity and durability of clinical response for individual patients.

\section{CONFLICT OF INTEREST}

The authors declare no conflict of interest.

\section{REFERENCES}

Anagnostou V, Smith KN, Forde PM, Niknafs N, Bhattacharya R, White J, Zhang T, Adleff V, Phallen J, Wali N, Hruban C, Guthrie VB, Rodgers K, Naidoo J, Kang H, Sharfman W, Georgiades C, Verde F, Illei P, Li QK, Gabrielson E, Brock MV, Zahnow CA, Baylin SB, Scharpf RB, Brahmer JR, Karchin R, Pardoll DM, Velculescu VE (2016) Evolution of neoantigen landscape during immune checkpoint blockade in non-small cell lung cancer. Cancer Discov 7(3): 264-276.

Ansell SM, Lesokhin AM, Borrello I, Halwani A, Scott EC, Gutierrez M, Schuster SJ, Millenson MM, Cattry D, Freeman GJ, Rodig SJ, Chapuy B, Ligon AH, Zhu L, Grosso JF, Kim SY, Timmerman JM, Shipp MA, Armand P (2015) PD-1 blockade with nivolumab in relapsed or refractory Hodgkin's lymphoma. N Engl J Med 372(4): 311-319.

Arlauckas SP, Garris CS, Kohler RH, Kitaoka M, Cuccarese MF, Yang KS, Miller MA, Carlson JC, Freeman GJ, Anthony RM, Weissleder R, Pittet MJ (2017) In vivo imaging reveals a tumour-associated macrophage-mediated resistance pathway in anti-PD-1 therapy. Sci Transl Med; e-pub ahead of print 10 May 2017; doi: 10.1126/scitranslmed.aal3604.

Benci JL, Xu B, Qiu Y, Wu TJ, Dada H, Twyman-Saint Victor C, Cucolo L, Lee DS, Pauken KE, Huang AC, Gangadhar TC, Amaravadi RK, Schuchter LM, Feldman MD, Ishwaran H, Vonderheide RH, Maity A, Wherry EJ, Minn AJ (2016) Tumor interferon signaling regulates a multigenic resistance program to immune checkpoint blockade. Cell 167(6): 1540-1554 e12.

Blackburn SD, Shin H, Freeman GJ, Wherry EJ (2008) Selective expansion of a subset of exhausted CD8 T cells by alphaPD-L1 blockade. Proc Natl Acad Sci USA 105(39): 15016-15021.

Bronte V, Kasic T, Gri G, Gallana K, Borsellino G, Marigo I, Battistini L, Iafrate M, Prayer-Galetti T, Pagano F, Viola A (2005) Boosting antitumour responses of T lymphocytes infiltrating human prostate cancers. J Exp Med 201(8): 1257-1268.

Buque A, Bloy N, Aranda F, Castoldi F, Eggermont A, Cremer I, Fridman WH, Fucikova J, Galon J, Marabelle A, Spisek R, Tartour E, Zitvogel L, Kroemer G, Galluzzi L (2015) Trial Watch: immunomodulatory monoclonal antibodies for oncological indications. Oncoimmunology 4(4): e1008814.

Chen PL, Roh W, Reuben A, Cooper ZA, Spencer CN, Prieto PA, Miller JP, Bassett RL, Gopalakrishnan V, Wani K, Petaccia De Macedo M, Austin-Breneman JL, Jiang H, Chang Q, Reddy SM, Chen WS, Tetzlaff MT, Broaddus RJ, Davies MA, Gershenwald JE, Haydu L, Lazar AJ, Patel SP, Hwu P, Hwu WJ, Diab A, Glitza IC, Woodman SE, Vence LM,
Wistuba, Amaria RN, Kwong LN, Prieto V, Davis RE, Ma W, Overwijk WW, Sharpe AH, Hu J, Futreal PA, Blando J, Sharma P, Allison JP, Chin L, Wargo JA (2016) Analysis of immune signatures in longitudinal tumour samples yields insight into biomarkers of response and mechanisms of resistance to immune checkpoint blockade. Cancer Discov 6(8): 827-837.

Chiappinelli KB, Strissel PL, Desrichard A, Li H, Henke C, Akman B, Hein A, Rote NS, Cope LM, Snyder A, Makarov V, Budhu S, Slamon DJ, Wolchok JD, Pardoll DM, Beckmann MW, Zahnow CA, Merghoub T, Chan TA, Baylin SB, Strick R (2015) Inhibiting DNA methylation causes an interferon response in cancer via dsRNA including endogenous retroviruses. Cell 162(5): 974-986.

Daud AI, Loo K, Pauli ML, Sanchez-Rodriguez R, Sandoval PM, Taravati K, Tsai K, Nosrati A, Nardo L, Alvarado MD, Algazi AP, Pampaloni MH, Lobach, Hwang J, Pierce RH, Gratz IK, Krummel MF, Rosenblum MD (2016) Tumor immune profiling predicts response to anti-PD-1 therapy in human melanoma. J Clin Invest 126(9): 3447-3452.

Farber DL, Yudanin NA, Restifo NP (2014) Human memory T cells: generation, compartmentalization and homeostasis. Nat Rev Immunol 14(1): 24-35.

Friedman AA, Letai A, Fisher DE, Flaherty KT (2015) Precision medicine for cancer with next-generation functional diagnostics. Nat Rev Cancer 15(12): 747-756.

Gajewski TF, Schreiber H, Fu YX (2013) Innate and adaptive immune cells in the tumour microenvironment. Nat Immunol 14(10): 1014-1022.

George S, Miao D, Demetri GD, Adeegbe D, Rodig SJ, Shukla S, Lipschitz M, Amin-Mansour A, Raut CP, Carter SL, Hammerman P, Freeman GJ, Wu CJ, Ott PA, Wong KK, Van Allen EM (2017) Loss of PTEN is associated with resistance to anti-PD-1 checkpoint blockade therapy in metastatic uterine leiomyosarcoma. Immunity 46(2): 197-204.

Goel S, DeCristo MJ, Watt AC, BrinJones H, Sceneay J, Li BB, Khan N, Ubellacker JM, Xie S, Metzger-Filho O, Hoog J, Ellis MJ, Ma CX, Ramm S, Krop IE, Winer EP, Roberts TM, Kim HJ, McAllister SS, Zhao JJ (2017) CDK4/6 inhibition triggers anti-tumour immunity. Nature 548(7668): 471-475.

Gubin MM, Zhang X, Schuster H, Caron E, Ward JP, Noguchi T, Ivanova Y, Hundal J, Arthur CD, Krebber WJ, Mulder GE, Toebes M, Vesely MD, Lam SS, Korman AJ, Allison JP, Freeman GJ, Sharpe AH, Pearce EL, Schumacher TN, Aebersold R, Rammensee HG, Melief CJ, Mardis ER, Gillanders WE, Artyomov MN, Schreiber RD (2014) Checkpoint blockade cancer immunotherapy targets tumour-specific mutant antigens. Nature 515(7528): 577-581.

Guillerey C, Huntington ND, Smyth MJ (2016) Targeting natural killer cells in cancer immunotherapy. Nat Immunol 17(9): 1025-1036.

Harty JT, Badovinac VP (2008) Shaping and reshaping CD8 + T-cell memory. Nat Rev Immunol 8(2): 107-119.

He R, Hou S, Liu C, Zhang A, Bai Q, Han M, Yang Y, Wei G, Shen T, Yang X, Xu L, Chen X, Hao Y, Wang P, Zhu C, Ou J, Liang H, Ni T, Zhang X, Zhou X, Deng K, Chen Y, Luo Y, Xu J, Qi H, Wu Y, Ye L (2016) Follicular CXCR5- expressing CD8 $(+)$ T cells curtail chronic viral infection. Nature 537(7620): 412-428.

Heninger E, Krueger TE, Lang JM (2015) Augmenting antitumour immune responses with epigenetic modifying agents. Front Immunol 6: 29.

Highfill SL, Cui Y, Giles AJ, Smith JP, Zhang H, Morse E, Kaplan RN, Mackall CL (2014) Disruption of CXCR2-mediated MDSC tumour trafficking enhances anti-PD1 efficacy. Sci Transl Med 6(237): 237 ra67.

Hirt C, Papadimitropoulos A, Mele V, Muraro MG, Mengus C, Iezzi G, Terracciano L, Martin I, Spagnoli GC (2014) 'In vitro' 3D models of tumour-immune system interaction. Adv Drug Deliv Rev 79-80: 145-154.

Huang AC, Postow MA, Orlowski RJ, Mick R, Bengsch B, Manne S, Xu W, Harmon S, Giles JR, Wenz B, Adamow M, Kuk D, Panageas KS, Carrera C, Wong P, Quagliarello F, Wubbenhorst B, D’Andrea K, Pauken KE, Herati RS, Staupe RP, Schenkel JM, McGettigan S, Kothari S, George SM, Vonderheide RH, Amaravadi RK, Karakousis GC, Schuchter LM, Xu X, Nathanson KL, Wolchok JD, Gangadhar TC, Wherry EJ (2017) T-cell invigoration to tumour burden ratio associated with anti-PD-1 response. Nature 545(7652): 60-65.

Hugo W, Shi H, Sun L, Piva M, Song C, Kong X, Moriceau G, Hong A, Dahlman KB, Johnson DB, Sosman JA, Ribas A, Lo RS (2015) Non-genomic and immune evolution of melanoma acquiring MAPKi resistance. Cell 162(6): 1271-1285.

Hugo W, Zaretsky JM, Sun L, Song C, Moreno BH, Hu-Lieskovan S, Berent-Maoz B, Pang J, Chmielowski B, Cherry G, Seja E, Lomeli S, Kong X, Kelley MC, Sosman JA, Johnson DB, Ribas A, Lo RS (2016) 
Genomic and transcriptomic features of response to anti-PD-1 therapy in metastatic melanoma. Cell 165(1): 35-44.

Im SJ, Hashimoto M, Gerner MY, Lee J, Kissick HT, Burger MC, Shan Q, Hale JS, Lee J, Nasti TH, Sharpe AH, Freeman GJ, Germain RN, Nakaya HI, Xue HH, Ahmed R (2016) Defining CD8 + T cells that provide the proliferative burst after PD-1 therapy. Nature 537(7620): 417-421.

Joyce JA, Fearon DT (2015) T cell exclusion, immune privilege, and the tumour microenvironment. Science 348(6230): 74-80.

Juneja VR, McGuire KA, Manguso RT, LaFleur MW, Collins N, Haining WN, Freeman GJ, Sharpe AH (2017) PD-L1 on tumour cells is sufficient for immune evasion in immunogenic tumours and inhibits CD8 T cell cytotoxicity. J Exp Med 214(4): 895-904.

Keir ME, Butte MJ, Freeman GJ, Sharpe AH (2008) PD-1 and its ligands in tolerance and immunity. Annu Rev Immunol 26: 677-704.

Kim K, Skora AD, Li Z, Liu Q, Tam AJ, Blosser RL, Diaz LA Jr, Papadopoulos N, Kinzler KW, Vogelstein B, Zhou S (2014) Eradication of metastatic mouse cancers resistant to immune checkpoint blockade by suppression of myeloid-derived cells. Proc Natl Acad Sci USA 111(32): 11774-11779.

Kluger HM, Zito CR, Turcu G, Baine M, Zhang H, Adeniran A, Sznol M, Rimm DL, Kluger Y, Chen L, Cohen JV, Jilaveanu LB (2017) PD-L1 studies across tumour types, its differential expression and predictive value in patients treated with immune checkpoint inhibitors. Clin Cancer Res 23(15): 4270-4279.

Konieczkowski DJ, Johannessen CM, Abudayyeh O, Kim JW, Cooper ZA, Piris A, Frederick DT, Barzily-Rokni M, Straussman R, Haq R, Fisher DE, Mesirov JP, Hahn WC, Flaherty KT, Wargo JA, Tamayo P, Garraway LA (2014) A melanoma cell state distinction influences sensitivity to MAPK pathway inhibitors. Cancer Discov 4(7): 816-827.

Koyama S, Akbay EA, Li YY, Aref AR, Skoulidis F, Herter-Sprie GS, Buczkowski KA, Liu Y, Awad MM, Denning WL, Diao L, Wang J, Parra-Cuentas ER, Wistuba, Soucheray M, Thai T, Asahina H, Kitajima S, Altabef A, Cavanaugh JD, Rhee K, Gao P, Zhang H, Fecci PE, Shimamura T, Hellmann MD, Heymach JV, Hodi FS, Freeman GJ, Barbie DA, Dranoff G, Hammerman PS, Wong KK (2016a) STK11/LKB1 deficiency promotes neutrophil recruitment and proinflammatory cytokine production to suppress T-cell activity in the lung tumour microenvironment. Cancer Res 76(5): 999-1008.

Koyama S, Akbay EA, Li YY, Herter-Sprie GS, Buczkowski KA, Richards WG, Gandhi L, Redig AJ, Rodig SJ, Asahina H, Jones RE, Kulkarni MM, Kuraguchi M, Palakurthi S, Fecci PE, Johnson BE, Janne PA, Engelman JA, Gangadharan SP, Costa DB, Freeman GJ, Bueno R, Hodi FS, Dranoff G, Wong KK, Hammerman PS (2016b) Adaptive resistance to therapeutic PD-1 blockade is associated with upregulation of alternative immune checkpoints. Nat Commun 7: 10501.

Larkin J, Hodi FS, Wolchok JD (2015) Combined nivolumab and ipilimumab or monotherapy in untreated melanoma. N Engl J Med 373(13): 1270-1271.

Lau J, Cheung J, Navarro A, Lianoglou S, Haley B, Totpal K, Sanders L, Koeppen H, Caplazi P, McBride J, Chiu H, Hong R, Grogan J, Javinal V, Yauch R, Irving B, Belvin M, Mellman I, Kim JM, Schmidt M (2017) Tumour and host cell PD-L1 is required to mediate suppression of antitumour immunity in mice. Nat Commun 8: 14572.

Lawrence MS, Stojanov P, Polak P, Kryukov GV, Cibulskis K, Sivachenko A, Carter SL, Stewart C, Mermel CH, Roberts SA, Kiezun A, Hammerman PS, McKenna A, Drier Y, Zou L, Ramos AH, Pugh TJ, Stransky N, Helman E, Kim J, Sougnez C, Ambrogio L, Nickerson E, Shefler E, Cortes ML, Auclair D, Saksena G, Voet D, Noble M, DiCara D, Lin P, Lichtenstein L, Heiman DI, Fennell T, Imielinski M, Hernandez B, Hodis E, Baca S, Dulak AM, Lohr J, Landau DA, Wu CJ, Melendez-Zajgla J, Hidalgo-Miranda A, Koren A, McCarroll SA, Mora J, Lee RS, Crompton B, Onofrio R, Parkin M, Winckler W, Ardlie K, Gabriel SB, Roberts CW, Biegel JA, Stegmaier K, Bass AJ, Garraway LA, Meyerson M, Golub TR, Gordenin DA, Sunyaev S, Lander ES, Getz G (2013) Mutational heterogeneity in cancer and the search for new cancer-associated genes. Nature 499(7457): 214-218.

Le DT, Durham JN, Smith KN, Wang H, Bartlett BR, Aulakh LK, Lu S, Kemberling H, Wilt C, Luber BS, Wong F, Azad NS, Rucki AA, Laheru D, Donehower R, Zaheer A, Fisher GA, Crocenzi TS, Lee JJ, Greten TF, Duffy AG, Ciombor KK, Eyring AD, Lam BH, Joe A, Kang SP, Holdhoff M, Danilova L, Cope L, Meyer C, Zhou S, Goldberg RM, Armstrong DK, Bever KM, Fader AN, Taube J, Housseau F, Spetzler D, Xiao N, Pardoll DM, Papadopoulos N, Kinzler KW, Eshleman JR, Vogelstein B, Anders RA, Diaz LA Jr (2017) Mismatch-repair deficiency predicts response of solid tumours to PD-1 blockade. Science 357(6349): 409-413.
Le DT, Uram JN, Wang H, Bartlett BR, Kemberling H, Eyring AD, Skora AD, Luber BS, Azad NS, Laheru D, Biedrzycki B, Donehower RC, Zaheer A, Fisher GA, Crocenzi TS, Lee JJ, Duffy SM, Goldberg RM, de la Chapelle A, Koshiji M, Bhaijee F, Huebner T, Hruban RH, Wood LD, Cuka N, Pardoll DM, Papadopoulos N, Kinzler KW, Zhou S, Cornish TC, Taube JM, Anders RA, Eshleman JR, Vogelstein B, Diaz LA Jr (2015) PD-1 blockade in tumours with mismatch-repair deficiency. $N$ Engl J Med 372(26): 2509-2520.

Leong YA, Chen Y, Ong HS, Wu D, Man K, Deleage C, Minnich M, Meckiff BJ, Wei Y, Hou Z, Zotos D, Fenix KA, Atnerkar A, Preston S, Chipman JG, Beilman GJ, Allison CC, Sun L, Wang P, Xu J, Toe JG, Lu HK, Tao Y, Palendira U, Dent AL, Landay AL, Pellegrini M, Comerford I, McColl SR, Schacker TW, Long HM, Estes JD, Busslinger M, Belz GT, Lewin SR, Kallies A, Yu D (2016) CXCR5(+) follicular cytotoxic T cells control viral infection in B cell follicles. Nat Immunol 17(10): 1187-1196.

Mahoney KM, Rennert PD, Freeman GJ (2015) Combination cancer immunotherapy and new immunomodulatory targets. Nat Rev Drug Discov 14(8): 561-584.

Manguso RT, Pope HW, Zimmer MD, Brown FD, Yates KB, Miller BC, Collins NB, Bi K, LaFleur MW, Juneja VR, Weiss SA, Lo J, Fisher DE, Miao D, Van Allen E, Root DE, Sharpe AH, Doench JG, Haining WN (2017) In vivo CRISPR screening identifies Ptpn2 as a cancer immunotherapy target. Nature 547(7664): 413-418.

Marincola FM, Jaffee EM, Hicklin DJ, Ferrone S (2000) Escape of human solid tumours from T-cell recognition: molecular mechanisms and functional significance. Adv Immunol 74: 181-273.

McGranahan N, Furness AJ, Rosenthal R, Ramskov S, Lyngaa R, Saini SK, Jamal-Hanjani M, Wilson GA, Birkbak NJ, Hiley CT, Watkins TB, Shafi S, Murugaesu N, Mitter R, Akarca AU, Linares J, Marafioti T, Henry JY, Van Allen EM, Miao D, Schilling B, Schadendorf D, Garraway LA, Makarov V, Rizvi NA, Snyder A, Hellmann MD, Merghoub T, Wolchok JD, Shukla SA, Wu CJ, Peggs KS, Chan TA, Hadrup SR, Quezada SA, Swanton C (2016) Clonal neoantigens elicit T cell immunoreactivity and sensitivity to immune checkpoint blockade. Science 351(6280): 1463-1469.

Mondanelli G, Bianchi R, Pallotta MT, Orabona C, Albini E, Iacono A, Belladonna ML, Vacca C, Fallarino F, Macchiarulo A, Ugel S, Bronte V, Gevi F, Zolla L, Verhaar A, Peppelenbosch M, Mazza EM, Bicciato S, Laouar Y, Santambrogio L, Puccetti P, Volpi C, Grohmann U (2017) A relay pathway between arginine and tryptophan metabolism confers immunosuppressive properties on dendritic cells. Immunity 46(2): 233-244.

Ngiow SF, Young A, Jacquelot N, Yamazaki T, Enot D, Zitvogel L, Smyth MJ (2015) A threshold level of intratumour CD8 + T-cell PD1 expression dictates therapeutic response to anti-PD1. Cancer Res 75(18): 3800-3811.

O'Donnell JS, Long GV, Scolyer RA, Teng MW, Smyth MJ (2017) Resistance to PD1/PDL1 checkpoint inhibition. Cancer Treat Rev 52: 71-81.

Ott PA, Hu Z, Keskin DB, Shukla SA, Sun J, Bozym DJ, Zhang W, Luoma A, Giobbie-Hurder A, Peter L, Chen C, Olive O, Carter TA, Li S, Lieb DJ, Eisenhaure T, Gjini E, Stevens J, Lane WJ, Javeri I, Nellaiappan K, Salazar AM, Daley H, Seaman M, Buchbinder EI, Yoon CH, Harden M, Lennon N, Gabriel S, Rodig SJ, Barouch DH, Aster JC, Getz G, Wucherpfennig K, Neuberg D, Ritz J, Lander ES, Fritsch EF, Hacohen N, Wu CJ (2017) An immunogenic personal neoantigen vaccine for patients with melanoma. Nature 547(7662): 217-221.

Paley MA, Kroy DC, Odorizzi PM, Johnnidis JB, Dolfi DV, Barnett BE, Bikoff EK, Robertson EJ, Lauer GM, Reiner SL, Wherry EJ (2012) Progenitor and terminal subsets of CD8 $+\mathrm{T}$ cells cooperate to contain chronic viral infection. Science 338(6111): 1220-1225.

Pardoll DM (2012) The blockade of immune checkpoints in cancer immunotherapy. Nat Rev Cancer 12(4): 252-264.

Pauken KE, Sammons MA, Odorizzi PM, Manne S, Godec J, Khan O, Drake AM, Chen Z, Sen DR, Kurachi M, Barnitz RA, Bartman C, Bengsch B, Huang AC, Schenkel JM, Vahedi G, Haining WN, Berger SL, Wherry EJ (2016) Epigenetic stability of exhausted T cells limits durability of reinvigoration by PD-1 blockade. Science 354(6316): 1160-1165.

Peng D, Kryczek I, Nagarsheth N, Zhao L, Wei S, Wang W, Sun Y, Zhao E, Vatan L, Szeliga W, Kotarski J, Tarkowski R, Dou Y, Cho K, Hensley-Alford S, Munkarah A, Liu R, Zou W (2015) Epigenetic silencing of TH1-type chemokines shapes tumour immunity and immunotherapy. Nature 527(7577): 249-253.

Peng W, Chen JQ, Liu C, Malu S, Creasy C, Tetzlaff MT, Xu C, McKenzie JA, Zhang C, Liang X, Williams LJ, Deng W, Chen G, Mbofung R, Lazar AJ, Torres-Cabala CA, Cooper ZA, Chen PL, Tieu TN, Spranger S, Yu X, Bernatchez C, Forget MA, Haymaker C, Amaria R, McQuade JL, Glitza IC, 
Cascone T, Li HS, Kwong LN, Heffernan TP, Hu J, Bassett Jr RL, Bosenberg MW, Woodman SE, Overwijk WW, Lizee G, Roszik J, Gajewski TF, Wargo JA, Gershenwald JE, Radvanyi L, Davies MA, Hwu P (2016) Loss of PTEN promotes resistance to T cell-mediated immunotherapy. Cancer Discov 6(2): 202-216.

Philip M, Fairchild L, Sun L, Horste EL, Camara S, Shakiba M, Scott AC, Viale A, Lauer P, Merghoub T, Hellmann MD, Wolchok JD, Leslie CS, Schietinger A (2017) Chromatin states define tumour-specific T cell dysfunction and reprogramming. Nature 545(7655): 452-456.

Pitt JM, Vetizou M, Daillere R, Roberti MP, Yamazaki T, Routy B, Lepage P, Boneca IG, Chamaillard M, Kroemer G, Zitvogel L (2016) Resistance mechanisms to immune-checkpoint blockade in cancer: tumour-intrinsic and -extrinsic factors. Immunity 44(6): 1255-1269.

Platten M, von Knebel Doeberitz N, Oezen I, Wick W, Ochs K (2014) Cancer immunotherapy by targeting IDO1/TDO and their downstream effectors. Front Immunol 5: 673.

Postow MA, Chesney J, Pavlick AC, Robert C, Grossmann K, McDermott D, Linette GP, Meyer N, Giguere JK, Agarwala SS, Shaheen M, Ernstoff MS, Minor D, Salama AK, Taylor M, Ott PA, Rollin LM, Horak C, Gagnier P, Wolchok JD, Hodi FS (2015) Nivolumab and ipilimumab versus ipilimumab in untreated melanoma. N Engl J Med 372(21): 2006-2017.

Reck M, Rodriguez-Abreu D, Robinson AG, Hui R, Csoszi T, Fulop A, Gottfried M, Peled N, Tafreshi A, Cuffe S, O’Brien M, Rao S, Hotta K, Leiby MA, Lubiniecki GM, Shentu Y, Rangwala R, Brahmer JR, Investigators K (2016) Pembrolizumab versus chemotherapy for PD-L1positive non-small-cell lung cancer. N Engl J Med 375(19): 1823-1833.

Restifo NP, Smyth MJ, Snyder A (2016) Acquired resistance to immunotherapy and future challenges. Nat Rev Cancer 16(2): 121-126.

Ribas A, Hamid O, Daud A, Hodi FS, Wolchok JD, Kefford R, Joshua AM, Patnaik A, Hwu WJ, Weber JS, Gangadhar TC, Hersey P, Dronca R, Joseph RW, Zarour H, Chmielowski B, Lawrence DP, Algazi A, Rizvi NA, Hoffner B, Mateus C, Gergich K, Lindia JA, Giannotti M, Li XN, Ebbinghaus S, Kang SP, Robert C (2016a) Association of pembrolizumab with tumour response and survival among patients with advanced melanoma. JAMA 315(15): 1600-1609.

Ribas A, Shin DS, Zaretsky J, Frederiksen J, Cornish A, Avramis E, Seja E, Kivork C, Siebert J, Kaplan-Lefko P, Wang X, Chmielowski B, Glaspy JA, Tumeh PC, Chodon T, Pe'er D, Comin-Anduix B (2016b) PD-1 blockade expands intratumoural memory T cells. Cancer Immunol Res 4(3): 194-203.

Rooney MS, Shukla SA, Wu CJ, Getz G, Hacohen N (2015) Molecular and genetic properties of tumours associated with local immune cytolytic activity. Cell 160(1-2): 48-61.

Roulois D, Loo Yau H, Singhania R, Wang Y, Danesh A, Shen SY, Han H, Liang G, Jones PA, Pugh TJ, O’Brien C, De Carvalho DD (2015) DNAdemethylating agents target colorectal cancer cells by inducing viral mimicry by endogenous transcripts. Cell 162(5): 961-973.

Sahin U, Derhovanessian E, Miller M, Kloke BP, Simon P, Lower M, Bukur V, Tadmor AD, Luxemburger U, Schrors B, Omokoko T, Vormehr M, Albrecht C, Paruzynski A, Kuhn AN, Buck J, Heesch S, Schreeb KH, Muller F, Ortseifer I, Vogler I, Godehardt E, Attig S, Rae R, Breitkreuz A, Tolliver C, Suchan M, Martic G, Hohberger A, Sorn P, Diekmann J, Ciesla J, Waksmann O, Bruck AK, Witt M, Zillgen M, Rothermel A, Kasemann B, Langer D, Bolte S, Diken M, Kreiter S, Nemecek R, Gebhardt C, Grabbe S, Holler C, Utikal J, Huber C, Loquai C, Tureci O (2017) Personalized RNA mutanome vaccines mobilize poly-specific therapeutic immunity against cancer. Nature 547(7662): 222-226.

Sakuishi K, Apetoh L, Sullivan JM, Blazar BR, Kuchroo VK, Anderson AC (2010) Targeting Tim-3 and PD-1 pathways to reverse T cell exhaustion and restore anti-tumour immunity. J Exp Med 207(10): 2187-2194.

Schadendorf D, Hodi FS, Robert C, Weber JS, Margolin K, Hamid O, Patt D, Chen TT, Berman DM, Wolchok JD (2015) Pooled analysis of long-term survival data from phase II and phase III trials of ipilimumab in unresectable or metastatic melanoma. J Clin Oncol 33(17): 1889-1894.

Schumacher TN, Schreiber RD (2015) Neoantigens in cancer immunotherapy. Science 348(6230): 69-74

Sen DR, Kaminski J, Barnitz RA, Kurachi M, Gerdemann U, Yates KB, Tsao HW, Godec J, LaFleur MW, Brown FD, Tonnerre P, Chung RT, Tully DC, Allen TM, Frahm N, Lauer GM, Wherry EJ, Yosef N, Haining WN (2016) The epigenetic landscape of T cell exhaustion. Science 354(6316): $1165-1169$.

Sharma P, Hu-Lieskovan S, Wargo JA, Ribas A (2017) Primary, adaptive, and acquired resistance to cancer immunotherapy. Cell 168(4): 707-723.
Shin DS, Zaretsky JM, Escuin-Ordinas H, Garcia-Diaz A, Hu-Lieskovan S, Kalbasi A, Grasso CS, Hugo W, Sandoval S, Torrejon DY, Palaskas N, Rodriguez GA, Parisi G, Azhdam A, Chmielowski B, Cherry G, Seja E, Berent-Maoz B, Shintaku IP, Le DT, Pardoll DM, Diaz Jr LA, Tumeh PC, Graeber TG, Lo RS, Comin-Anduix B, Ribas A (2017) Primary resistance to PD-1 blockade mediated by JAK1/2 mutations. Cancer Discov 7(2): 188-201.

Simpson TR, Li F, Montalvo-Ortiz W, Sepulveda MA, Bergerhoff K, Arce F, Roddie C, Henry JY, Yagita H, Wolchok JD, Peggs KS, Ravetch JV, Allison JP, Quezada SA (2013) Fc-dependent depletion of tumour-infiltrating regulatory $\mathrm{T}$ cells co-defines the efficacy of anti-CTLA-4 therapy against melanoma. J Exp Med 210(9): 1695-1710.

Smyth MJ, Ngiow SF, Ribas A, Teng MW (2016) Combination cancer immunotherapies tailored to the tumour microenvironment. Nat Rev Clin Oncol 13(3): 143-158.

Spranger S, Bao R, Gajewski TF (2015) Melanoma-intrinsic beta-catenin signalling prevents anti-tumour immunity. Nature 523(7559): 231-235.

Spranger S, Gajewski T (2013) Rational combinations of immunotherapeutics that target discrete pathways. J Immunother Cancer 1: 16.

Spranger S, Spaapen RM, Zha Y, Williams J, Meng Y, Ha TT, Gajewski TF (2013) Up-regulation of PD-L1, IDO, and T(regs) in the melanoma tumour microenvironment is driven by $\mathrm{CD} 8(+) \mathrm{T}$ cells. Sci Transl Med 5(200): 200ra116.

Takeda K, Nakayama M, Hayakawa Y, Kojima Y, Ikeda H, Imai N, Ogasawara K, Okumura K, Thomas DM, Smyth MJ (2017) IFN-gamma is required for cytotoxic $\mathrm{T}$ cell-dependent cancer genome immunoediting. Nat Commun 8: 14607.

Thommen DS, Schreiner J, Muller P, Herzig P, Roller A, Belousov A, Umana P, Pisa P, Klein C, Bacac M, Fischer OS, Moersig W, Savic Prince S, Levitsky V, Karanikas V, Lardinois D, Zippelius A (2015) Progression of lung cancer is associated with increased dysfunction of $\mathrm{T}$ cells defined by coexpression of multiple inhibitory receptors. Cancer Immunol Res 3(12): 1344-1355.

Topalian SL, Drake CG, Pardoll DM (2015) Immune checkpoint blockade: a common denominator approach to cancer therapy. Cancer Cell 27(4): 450-461.

Utzschneider DT, Charmoy M, Chennupati V, Pousse L, Ferreira DP, Calderon-Copete S, Danilo M, Alfei F, Hofmann M, Wieland D, Pradervand S, Thimme R, Zehn D, Held W (2016) T cell factor 1expressing memory-like $\mathrm{CD} 8(+) \mathrm{T}$ cells sustain the immune response to chronic viral infections. Immunity 45(2): 415-427.

Van Allen EM, Miao D, Schilling B, Shukla SA, Blank C, Zimmer L, Sucker A, Hillen U, Geukes Foppen MH, Goldinger SM, Utikal J, Hassel JC, Weide B, Kaehler KC, Loquai C, Mohr P, Gutzmer R, Dummer R, Gabriel S, Wu CJ, Schadendorf D, Garraway LA (2015) Genomic correlates of response to CTLA-4 blockade in metastatic melanoma. Science 350(6257): 207-211.

Wei SC, Levine JH, Cogdill AP, Zhao Y, Anang NAS, Andrews MC, Sharma P, Wang J, Wargo JA, Pe'er D, Allison JP (2017) Distinct cellular mechanisms underlie anti-CTLA-4 and anti-PD-1 checkpoint blockade. Cell 170(6): 1120-1133.e17.

Woo SR, Turnis ME, Goldberg MV, Bankoti J, Selby M, Nirschl CJ, Bettini ML, Gravano DM, Vogel P, Liu CL, Tangsombatvisit S, Grosso JF, Netto G, Smeltzer MP, Chaux A, Utz PJ, Workman CJ, Pardoll DM, Korman AJ, Drake CG, Vignali DA (2012) Immune inhibitory molecules LAG-3 and PD-1 synergistically regulate T-cell function to promote tumoural immune escape. Cancer Res 72(4): 917-927.

Zaretsky JM, Garcia-Diaz A, Shin DS, Escuin-Ordinas H, Hugo W, HuLieskovan S, Torrejon DY, Abril-Rodriguez G, Sandoval S, Barthly L, Saco J, Homet Moreno B, Mezzadra R, Chmielowski B, Ruchalski K, Shintaku IP, Sanchez PJ, Puig-Saus C, Cherry G, Seja E, Kong X, Pang J, Berent-Maoz B, Comin-Anduix B, Graeber TG, Tumeh PC, Schumacher TN, Lo RS, Ribas A (2016) Mutations associated with acquired resistance to PD-1 blockade in melanoma. N Engl J Med 375(9): 819-829.

Zitvogel L, Pitt JM, Daillere R, Smyth MJ, Kroemer G (2016) Mouse models in oncoimmunology. Nat Rev Cancer 16(12): 759-773.

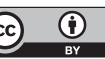

This work is licensed under the Creative Commons Attribution 4.0 International License. To view a copy of this license, visit http://creativecommons.org/licenses/by/4.0/

(C) The Author(s) named above 2018 